$\underline{\text { Review Article }}$

\title{
Hodgkin's Lymphoma in Older Patients: an Orphan Disease?
}

Antoine Thyss, Esma Saada, Lauris Gastaud, Frédéric Peyrade and Daniel Re

Haematology Department; Centre Antoine-Lacassagne, 33 Avenue de Valombrose, 06189 Nice cedex 2, France.

Correspondance to: Antoine Thyss. Haematology Department; Centre Antoine Lacassagne ,33 avenue de Valombrose, 06189 Nice cedex 2, France. E-mail: antoine.thyss@ nice.unicancer.fr

Competing interests: The authors have declared that no competing interests exist.

Published: July 1, 2014

Received: May 20, 2014

Accepted: June 20, 2014

Citation: Mediterr J Hematol Infect Dis 2014, 6(1): e2014050, DOI: 10.4084/MJHID.2014.050

This article is available from: http://www.mjhid.org/article/view/13485

This is an Open Access article distributed under the terms of the Creative Commons Attribution License (http://creativecommons.org/licenses/by/2.0), which permits unrestricted use, distribution, and reproduction in any medium, provided the original work is properly cited.

Abstract. Hodgkin Lymphoma HL can be cured in the large majority of younger patients, but prognosis for older patients, especially those with advanced-stage disease, has not improved substantially. The percentage of HL patients aged over 60 ranges between $15 \%$ and $35 \%$.A minority of them is enrolled into clinical trials. HL in the elderly have some specificities: more frequent male sex, B-symptoms, advanced stage, sub diaphragmatic presentation, higher percentage of mixed cellularity, up to $50 \%$ of advanced cases associated to EBV. Very old age (>70) and comorbidities are factor of further worsening prognosis. Like in younger patients, ABVD is the most used protocol, but treatment outcome remains much inferior with more frequent, severe and sometimes specific toxicities. Few prospective studies with specific protocols are available. The main data have been published by the Italian Lymphoma Group with the VEPEMB schedule and the German Hodgkin Study Group with the PVAG regimen. Recently, the Scotland and Newcastle Lymphoma Study Group published the SHIELD program associating a prospective phase 2 trial with VEPEMB and a prospective registration of others patients. Patients over 60y with early-stage disease received three cycles plus radiotherapy and had $81 \%$ of 3-year overall survival (OS).Those with advanced-stage disease received six cycles, with 3-year OS of 66\%.The role of geriatric and comorbidity assessment in the treatment's choice for HL in the elderly is a major challenge. The combination of loss of activities of daily living combined with the age stratification more or less $70 \mathrm{y}$ has been shown as a simple and effective survival model. Hopes come from promising new agents like brentuximab-vedotin (BV) a novel antibody-drug conjugate. The use of TEP to adapt the combination of chemotherapy and radiotherapy according to the metabolic response could also be way for prospective studies.

Introduction. Both the clinical management of older patients with cancer and the design of research studies pertinent to this population remain major challenges. This statement is particularly true for Hodgkin's
Lymphoma (HL): in younger patients, HL is cured in the vast majority, but results remain disappointing for older patients, especially those with advanced-stage disease. ${ }^{1}$ 
For the treatment of HL in elderly, there is a major contrast between the relative disease frequency in older patients and the rarity of the studies specially targeted at this population. HL in older patients is not a very rare disease: in the epidemiological data from the US government, the age adjusted incidence in 2006-2008 for $\mathrm{HL} \geq 65$ represents $17.7 \%$ of all HL. ${ }^{2}$ Populationbased epidemiological studies typically show a bimodal peak of HL incidence: ${ }^{1-11}$ the first around 30-35 years old, the second beyond 55-60. ${ }^{7}$

The proportion of HL patients aged $>60$ ranges in the different reports between $15 \%$ and $35 \%$; $9,9,10,11,12$ accordingly the $26.7 \%$ of biopsies of HL, collected between 2006-2011 in a database, grouping all pathologists of the department of the Alpes-Maritimes in the south of France, and including also our cancer centre, was from patients aged > 60 (unpublished data), Several recent series have specified the relative incidence of $\mathrm{HL}$ in the elderly and identified specific prognostic factors in this group of patients; ; $^{1,3-7,10,11,13,14}$ however, only a minority of them are enrolled in clinical trials. ${ }^{10}$

Specificity of HL in the Elderly. Age itself is one of the important prognostic factors in Hodgkin Lymphoma (HL) and is included in the prognostic scoring system of some of the main cooperative groups such as EORTC or Canadian-ECOG, as in the international prognostic index for advanced $\mathrm{HL}^{8}$ but not for the German Hodgkin Study Group, GHSG . For example, age over 50 is an unfavourable prognosis factor for the EORTC group. Patients over 60 are rarely eligible and/or included in the prospective trials of these groups. Moreover, International Prognostic Index (IPS) is the most used model for predicting prognosis in advanced-stage HL patients ${ }^{8}$ but it must be noted that no patient with an age $>65$ was enrolled in the study. Patients aged $>60$ years have a 5 -year event- free survival (EFS) and overall survival (OS) rate of $30-40 \%$ and $40 \%-50 \%$, respectively. ${ }^{12,15,16}$ These figures are significantly inferior to those reported in the adult patient. ${ }^{3}$ However, HL survival for all age groups increased in the last two decades, even in the age subset over 60 , where no major advances in treatment efficacy were recorded, indicating an overall improvement in patient care. ${ }^{1,3}$

Several reports stressed the difference in pathogenetic mechanisms, tumour pathobiology, hostrelated factors, clinical presentation, symptoms and prognosis for $\mathrm{HL}$ affecting the elderly as compared to the adult. ${ }^{4,5,13}$ There are many differences between the presentation of $\mathrm{HL}$ in the elderly in comparison to that of the younger patients: (a) mixed cellularity is more frequent ranging from $31 \%$ to $50 \% ;^{1,13}$ (b) $34 \%$ of cases and up to $50 \%$ of advanced cases show the presence of EBER or LMP-1 proteins in Reed-Sternberg cells ${ }^{6}$ (these two points are not independent); (c) Bsymptoms and advanced stage are much more common than in adults. ${ }^{7}$ Male sex and sub-diaphragmatic presentation are also more frequent in patients over 50 . Age over 70 is a factor of further worsening prognosis, ${ }^{1,9}$ as is co-morbidity. ${ }^{1}$ The latter seems to play an essential role in predicting treatment outcome: in a retrospective analysis, stage, B symptoms and presence of co-morbidity were independently associated with inferior survival. ${ }^{12}$ Several recent retrospective studies, mainly on population databases, have pointed out these particularities (table 1).

Management of HL in the Elderly. There is no true consensus for treatment of HL in the elderly. After full staging, including PET -scan, geriatric assessment and evaluation of co-morbidities, the principles of treatment can be resumed as follows: for stages 1A and2A, a short chemotherapy program of two cycles, possibly prolonged to four courses in case of poor risk

Table 1. Retrospective studies of elderly patients with HL.

\begin{tabular}{|c|c|c|c|c|}
\hline Author & Type of study & Population & Main Results & Ref \\
\hline $\begin{array}{l}\text { Stark GL } \\
2002\end{array}$ & $\begin{array}{l}\text { population based approach } \\
\text { Northen England }\end{array}$ & $\begin{array}{l}102 \mathrm{pts} \\
\geq 60 \mathrm{y}\end{array}$ & $\begin{array}{l}\text { in patients } \geq 70 \mathrm{y}: \\
\text { early stage } 36 \mathrm{~m} \text {, advanced } 14 \mathrm{~m} \quad \text { poorer survival for } \\
\text { EBV+ }\end{array}$ & 8 \\
\hline $\begin{array}{l}\text { Engert A } \\
(2005)\end{array}$ & $\begin{array}{l}\text { Older patient from GHSG } \\
\text { studies }\end{array}$ & $\begin{array}{l}372 \mathrm{pts} \geq \\
60 \mathrm{y}\end{array}$ & $\begin{array}{l}\text { poorer risk profil, more severe TR toxicity, higher motality } \\
\text { during treatment, lower dose intensity vs younger patients }\end{array}$ & 13 \\
\hline $\begin{array}{l}\text { Brenner H } \\
\quad(2008)\end{array}$ & $\begin{array}{l}\text { SEER data USA survival } \\
1980-82 \text { vs } 2007-04\end{array}$ & - & $\begin{array}{l}\text { age specific survival: absence of improvement in patient } \geq \\
60 y: 10 \text { y relative survival of } 44,9 \%\end{array}$ & 55 \\
\hline $\begin{array}{r}\text { Björkholm M } \\
(2011)\end{array}$ & $\begin{array}{l}\text { Population data Sweden } \\
\text { 1970-2006 }\end{array}$ & - & proportion of elderly pts : $21 \%>65 y ; 5 \% \geq 80 y$ & 57 \\
\hline $\begin{array}{l}\text { Evens AM } \\
\text { (2012) }\end{array}$ & Retrospective multicentre & $\begin{array}{l}94 \text { pts }(60- \\
89 y)\end{array}$ & $\begin{array}{l}\text { age }>70 \text { and loss of activities of dayly living only } \\
\text { prognostic factor }\end{array}$ & 56 \\
\hline
\end{tabular}


features, followed by involved fields (IF) radiotherapy. For advanced stage, it is often claimed that a prolonged use of ABVD (i.e. 6 cycles) could be also given to patients in good general status, but elderly patients are often incapable to tolerate the regimen of six cycles of ABVD, particularly because of the lung toxicity induced by bleomycin. There is no consensual approach for frail patients. The number of chemotherapy cycles might be reduced depending on the result of interim PET-scans, even if data for this approach in this elderly population are lacking.

The ABVD regimen (doxorubicin, bleomycin, vinblastine, and dacarbazine) has been considered the standard front-line treatment for HL patients ${ }^{17}$ and remains a gold standard, especially for limited-stage HL. Obviously, treatment outcomes with ABVD in elderly patients remain inferior to those obtained in younger patients. ${ }^{18}$ Moreover, toxicities are more frequent and severe in older patients, and treatment dose intensity is often reduced because of toxicity and/or co-morbidity and some specific toxicities are observed, as lung toxicity of bleomycin reported as high as $46 \%$ in some series. ${ }^{18,19}$

A frequent approach in geriatric oncology or haematology to reduce toxicity of chemotherapy is the development of specific protocols that reduce dose intensity and/or omit or replace some drugs with ageassociated toxicity. This approach often permits a better tolerance but is systematically associated with a reduction of response and survival, as compared to younger adult patients. For example, the role of relative dose intensity (RDI) has been questioned by the German Hodgkin Study Group (GHSG) in the elderly HL patient: a significantly lower RDI was observed in older HL patients ${ }^{2}$ and patients with a RDI $<65 \%$ had poorer outcomes than patients receiving higher chemotherapy doses. ${ }^{9}$

Taken together these data stress the concept that in elderly patients, non-HL events affect survival in a more significant way compared to younger patients.

In the late 1990s, the GHSG carried out a prospectively randomized study to compare the baseline BEACOPP regimen against COPP-ABVD, their standard regimen at the time. ${ }^{20}$ Between February 1993 and 1998, 75 patients aged 66 - 75 years with newly diagnosed $\mathrm{HL}$ in advanced stages were recruited into the HD9 trial as a separate stratum (HD9 elderly). Patients were assigned to eight alternating cycles of COPP and ABVD or eight cycles of BEACOPP in baseline doses. Radiotherapy was given to initially bulky or residual disease. In total, 68 of 75 registered patients were met assessment criteria: 26 with COPPABVD and 42 with BEACOPP baseline. There were no significant differences in terms of complete remission $(76 \%)$, overall survival $(50 \%)$, and freedom from treatment failure (FFTF) $(46 \%)$ at 5 years. Two patients $(8 \%)$ treated with COPP-ABVD and nine patients $(21 \%)$ treated with BEACOPP died of acute toxicity. They concluded that both regimens gave limited results in elderly patients, and that baseline BAECOPP was too toxic. The use of the escalated BEACOPP, the standard regimen of the GHSG for advanced stage $\mathrm{HL}$ in younger patients, is excluded for patients over 60 years because of excessive toxicity. ${ }^{21}$

Prospective HL Studies Specifically Designed for Older Patients. Very few prospective HL studies designed specifically for older patients are available. All studies published since 2000 are listed in Table 2. Some non-ABVD chemotherapy regimens containing different alkylating agents have been published and are also listed in Table 2.

Macpherson et al. have proposed in 2002 a new protocol called ODBEP (vincristine, doxorubicin, bleomycin, etoposide and prednisone). ${ }^{22}$ They compared 38 patients aged over 65 , treated with this regimen, with an historical control group of 17 patients treated with $\mathrm{MOPP} / \mathrm{ABV}$-variant, a standard regimen in the 1980s. With a median survival of 43 and 39 months, and five-year overall survival (OS) of $42 \%$ and $32 \%$, respectively, there was no statistically significant difference between the two treatments; however, ODBEP appeared to be less toxic.

The Italian Lymphoma Group Results published the results with the VEPEMB schedule (vinblastine, cyclophosphamide, prednisolone, procarbazine, etoposide, mitoxantrone and bleomycin). ${ }^{12}$ This study included 105 evaluable patients over 65 (mean 71 years, range 66-83), with 48 (46\%) stages I-IIA, and $57(54 \%)$ stages IIB-IV. Co-morbidity defined only as "the presence of a concomitant disease, requiring specific treatment" was observed in 39 patients (37\%). The CR rate was $76 \%$, respectively $98 \%$ for stage IIA and $58 \%$ for stage IIB-IV, and the five-year RFS rate of patients entering CR was $82 \%$, (respectively $95 \%$ and 66\%). In multivariate analysis, stage, systemic symptoms, and co-morbidity had independent value in affecting OS, DSS, and FFS. Surprisingly, despite the use of bleomycin, no pulmonary toxicity is mentioned, raising the question of this systematic evaluation.

The same regimen has been used by the Scotland and Newcastle Lymphoma study group (SNLG) in the SHIELD program ${ }^{23}$ for 175 patients, associating a prospective phase 2 trial of VEPEMB with 105 patients with a prospective registration study of patients not treated as part of the VEPEMB study. This trial included patients too frail to receive standard therapies and patients managed with curative intent using alternative treatment regimens, including 35 patients treated with ABVD. This somewhat complicated 
Table 2. Recent studies with specific regimen for patients over 60 years with HL.

\begin{tabular}{|c|c|c|c|c|c|c|c|c|}
\hline Study & Nb pts & Age & Protocol & Response & Survival & Toxicity & Comments & Ref \\
\hline $\begin{array}{l}\text { Macpherson } \\
\text { (2002) }\end{array}$ & 38 & $\begin{array}{c}>65 \\
\text { med } 72\end{array}$ & ODBEP & NR & $5 y$ OS $42 \%$ & $\begin{array}{l}\text { no toxic } \\
\text { death }\end{array}$ & $\begin{array}{l}\text { radiotherapy for } \\
\text { bulky med. }\end{array}$ & 53 \\
\hline $\begin{array}{l}\text { Levis } \\
(2004)\end{array}$ & 105 & $\begin{array}{c}>65 \\
\text { mean } 71\end{array}$ & VEPEMB & $\begin{array}{c}\text { CR } \\
\text { IIA } 98 \% \\
\text { IIB-IV } 58 \%\end{array}$ & $\begin{array}{c}5 y \text { RFS } \\
\text { IIA } 95 \% \\
\text { IIB-IV } 61 \%\end{array}$ & TRM $2 \%$ & $\begin{array}{l}\text { pronostic value of } \\
\text { "comorbidity" }\end{array}$ & 48 \\
\hline $\begin{array}{l}\text { Kolstad } \\
(2007)\end{array}$ & 29 & $\begin{array}{l}\geq 60 \\
\text { med } 71\end{array}$ & $\begin{array}{c}\text { CHOP 21 } \\
\text { stage I-IIA } \\
\text { 2-4+Rt } \\
\text { stage IIB-III } \\
\text { 6-8 + RT }\end{array}$ & CR 93\% & $\begin{array}{c}\text { stage I-IIA 3y } \\
\text { OS } 91 \% 3 y \\
\text { PFS } 82 \% \\
\text { stage IIB-IV } \\
\text { 3y OS } 67 \% \\
\text { 3y PFS } 72 \%\end{array}$ & $\begin{array}{l}2 \text { tox. } \\
\text { deaths }\end{array}$ & $\begin{array}{l}55 \% \text { with } \\
\text { comorbidities }\end{array}$ & 18 \\
\hline $\begin{array}{l}\text { Halbsguth } \\
\text { (2010) }\end{array}$ & 60 & $\begin{array}{l}60-75 \\
\text { med } 68\end{array}$ & $\begin{array}{l}\text { BACOPP } \\
6-8 \text { cycles }\end{array}$ & $\begin{array}{l}\text { CR/CRU } \\
85 \%\end{array}$ & $\begin{array}{l}3 \mathrm{Y} \text { PFS } 60 \% \\
3 \mathrm{Y} \text { OS } 71 \%\end{array}$ & $\begin{array}{c}\text { TRM 12\% } \\
\text { grade 3-4 } \\
87 \%\end{array}$ & $\begin{array}{l}\text { radiotherapy for } \\
\text { "residual mass" }\end{array}$ & 50 \\
\hline $\begin{array}{c}\text { Böll } \\
(2011)\end{array}$ & 59 & $\begin{array}{c}60-75 \\
\text { med } 66,7\end{array}$ & PVAG & $\begin{array}{c}\text { CR/CRU } \\
78 \%\end{array}$ & $\begin{array}{l}3 \mathrm{Y} \text { PFS } 58 \% \\
3 \mathrm{Y} \text { OS } 66 \%\end{array}$ & $\begin{array}{c}1 \text { tox. death } \\
\text { grade 3-4 } \\
75 \%\end{array}$ & $\begin{array}{l}\text { radiotherapy for } \\
\text { "residual mass" }\end{array}$ & 49 \\
\hline $\begin{array}{l}\text { Proctor } \\
(2012)\end{array}$ & 103 & $\begin{array}{c}>60 \\
\text { med } 73\end{array}$ & $\begin{array}{c}\text { VEPEMB } \\
\text { stage I-IIA } \\
\text { 3+Rt } \\
\text { stage IIB-III } \\
\text { 6+ RT }\end{array}$ & $\begin{array}{c}\text { stage I-IIA } \\
74 \% \mathrm{CR} \\
\text { stage IIB-IV } \\
61 \% \mathrm{CR}\end{array}$ & $\begin{array}{c}\text { stage I-IIA 3y } \\
\text { OS } 81 \% 3 y \\
\text { PFS } 74 \% \\
\text { stage IIB-IV } \\
\text { 3y OS 66\% } \\
\text { 3y PFS 58\% }\end{array}$ & TRM 7\% & $\begin{array}{l}\text { non frail patients } \\
\text { only }\end{array}$ & 46 \\
\hline
\end{tabular}

program was designed to recruit all patients representative of the target population in participating centers. Initial evaluation of the patients involved a formalized assessment of co-morbidity using a modified ACE-27 co-morbidity scale. Patients designated as "non-frail," were eligible for the phase 2 VEPEMB protocol. Those designated as "frail" were eligible for entry into the registration arm of the study and were treated at their physician's discretion. Of 103 VEPEMB patients over 60 (median age 73), 31 had early-stage disease (stage $1 \mathrm{~A} / 2 \mathrm{~A}$ ) and received VEPEMB three times, along with radiotherapy. The median follow-up was 36 months. Complete remission (CR) rate (intention-to-treat) was $74 \%$, and three-year overall survival (OS) and progression free survival (PFS) were $81 \%$ and $74 \%$, respectively. A total of 72 patients had advanced-stage disease (stage $1 \mathrm{~B} / 2 \mathrm{~B} / 3$ or 4 ) and received VEPEMB six times. CR rate was $61 \%$ with three-year OS and PFS of $66 \%$ and $58 \%$, respectively. Overall TRM was 7\%.

Another new regimen has been developed by the GHSG in the same period in early unfavorable and advanced stages, the PVAG regimen (prednisone, vinblastine, doxorubicin, and gemcitabine). ${ }^{24}$ In a phase 2 study, 59 patients with HL aged 60 to 75 (median, 68 years) and with "normal organ function" and good general condition (WHO-Index $\leq 2$ ) received 6 to 8 cycles of PVAG and additional radiotherapy if they were not in complete remission (CR) after chemotherapy. CR/CR uncertain was obtained in 46 patients $(78 \%)$. The three-year estimated for OS and PFS were $58 \%(95 \% \mathrm{CI}, 43 \%-71 \%)$ and $66 \%$ (95\% CI, $50 \%-78 \%$ ), respectively. WHO grade $3 / 4$ toxicities were documented in 43 patients $(73 \%)$, with one treatment-related death. These results are very close to those of their previous BACOPP regimen for survival, with less toxicity.

A study of Kolstad et al. (25) reported for the first time the results of the CHOP-21 regimen, largely used in non-Hodgkin's lymphoma. In this single institution's study with 29 patients aged 60 to 91, 11 stage-I/II patients received 2-4 cycle followed by radiotherapy and 18 stage-IIB/IV patients received 6-8 cycles, without radiotherapy for $13 / 18$. Two treatment-related deaths occurred, but the complete response rate of $\mathrm{CHOP} \pm$ radiotherapy was $93 \%$ and OS and PFS at three years were $79 \%$ and $76 \%$, respectively. Unfortunately, these impressive results of CHOP-21 in elderly HL as not been confirmed by other groups.

Studies Designed for Younger Patients but Including Patients over 60 Years. Other studies designed for younger patients have included patients aged over 60. They are listed in Table 3.

In 2002, the Nebraska Study Group in a retrospective comparison of ChlVPP vs. hybrid ChlVPP/ABV in 56 patients over 60 years, showed a major survival difference with a five-year OS of $30 \%$ vs. $67 \%$ respectively and conclude that adriamycin should be considered as a major component of the 
Table 3. Data for patients over 60y in studies designed for younger patients.

\begin{tabular}{|c|c|c|c|c|c|c|c|c|}
\hline Study & Nb pts & Age & Protocole & Response & Survival & Toxicity & Comments & Ref \\
\hline $\begin{array}{l}\text { Weekes } \\
\text { (2002) }\end{array}$ & 56 & $\geq 60$ & $\begin{array}{c}\text { ChlVPP } \\
\text { or } \\
\text { ChlVPP/ABV }\end{array}$ & $\mathrm{PR}+\mathrm{CR} 84 \%$ & $\begin{array}{c}5 y \text { OS } 30 \% \\
\text { or } \\
67 \%\end{array}$ & NR & $\begin{array}{l}\text { age only } \\
\text { pronostic factor } \\
\text { for pts }>60\end{array}$ & 54 \\
\hline $\begin{array}{l}\text { Ballova } \\
(2005)\end{array}$ & 68 & $\begin{array}{c}\text { 66-75 } \\
\text { Advanced }\end{array}$ & $\begin{array}{c}\text { COPP/ABVD } \\
\text { vs } \\
\text { BEACOPP - } \\
\text { baseline }\end{array}$ & CR 76\% & $\begin{array}{c}5 y \text { FFTF } \\
55 \% \text { vs } 74 \%\end{array}$ & $\begin{array}{l}\text { TRM } 2 \% \\
\text { vs } 8 \%\end{array}$ & $\begin{array}{l}\text { RT to bulky and } \\
\text { residual } \\
\text { mass }(26 \%)\end{array}$ & 51 \\
\hline $\begin{array}{l}\text { Klimm } \\
(2007)\end{array}$ & 89 & $\begin{array}{c}60 \\
\text { (med 65) } \\
\text { early } \\
\text { unfavorable }\end{array}$ & $\begin{array}{l}\text { COPP/ABVD } \\
+ \text { EFRT/IFRT }\end{array}$ & CR/CRU 93,5\% & $\begin{array}{c}5 y \text { FFTF } \\
64 \% \text { vs } 70 \%\end{array}$ & $\begin{array}{l}2 \% \text { of TRM } \\
\text { related to } \\
\text { EFRT }\end{array}$ & $\begin{array}{l}\text { negative impact } \\
\text { of EFRT vs IFRT }\end{array}$ & 55 \\
\hline $\begin{array}{l}\text { Evens } \\
(2013)\end{array}$ & 45 & $\geq 60$ & $\begin{array}{l}\text { ABVD } \times 6-8 \\
\text { vs } \\
\text { S.V } \times 12 \mathrm{w}\end{array}$ & $\begin{array}{c}\text { CR/CRU } \\
\text { ABVD 65\% } \\
\text { S.V } 62 \%\end{array}$ & $\begin{array}{l}\text { 3y OS 73\% } \\
\text { 3y FFS 56\% }\end{array}$ & TRM 9\% & $\begin{array}{l}\text { 24\% lung tox. } \\
\text { RT in } \\
\text { 8,7\% ABVD pts } \\
43 \% \text { S.V pts }\end{array}$ & 16 \\
\hline $\begin{array}{c}\text { Böll } \\
(2013)\end{array}$ & 117 & $\begin{array}{c}65-70 \\
\text { med } 65 \text { stage } \\
\text { I-IIA }\end{array}$ & $\begin{array}{c}\text { ABVD x } 4 \\
\text { IFRT 20-30 } \\
\text { gy }\end{array}$ & CR $89 \%$ & $\begin{array}{c}5 y \text { PFS } \\
75 \%\end{array}$ & $\begin{array}{l}\text { TRM 5\% } \\
\text { grade 3-4 } \\
\quad 68 \%\end{array}$ & $\begin{array}{l}\text { GHSG H10-H11 } \\
\text { studies }\end{array}$ & 45 \\
\hline
\end{tabular}

chemotherapy regimen in these patients. ${ }^{15}$ None of the usual clinical features were significant predictors of OS in patients above 60 .

In the multicenter HD8 study of the German Hodgkin's Study Group, 1064 patients with early-stage unfavorable $\mathrm{HL}$ were randomized to receive 4 cycles of chemotherapy (2 COPP alternated with 2 ABVD), followed by either radiotherapy (RT) of 30 Gy extended field (EF) + 10 Gy to bulky disease or $30 \mathrm{~Gy}$ involved field (IF) +10 Gy to bulky disease. Of these, 89 patients $(8.4 \%)$ were $\geq 60$ years. Acute toxicity from RT was more pronounced in elderly patients receiving EF-RT compared with IF-RT. Freedom from treatment failure (FFTF) $64 \%$ vs. $87 \%$, and OS $70 \%$ vs. $94 \%$ after 5 years was lower in elderly patients compared with younger patients. Elderly patients had poorer outcomes when treated with EF-RT compared with IF$\mathrm{RT}$ in terms of FFTF (58\% versus $70 \% ; \mathrm{P}=0.034)$ and OS (59\% versus $81 \% ; \mathrm{P}=0.008)$. The main conclusion was that EF-RT after chemotherapy has a negative impact on elderly patients with early-stage unfavorable HL and should be avoided. ${ }^{26}$

The German Hodgkin Study Group (GHSG) has tested the BACOPP regimen that consists of bleomycin, doxorubicin, cyclophosphamide, vincristine, procarbazine, and prednisone. ${ }^{27}$ Compared with the BEACOPP baseline, a regiment largely studied by this group, etoposide was omitted, and the anthracycline dose was increased as they considered that anthracyclines might be one of the most relevant components of chemotherapy for HL in older patients. Sixty five patients with early unfavorable or advanced stage HL, aged between 60 and 75 years, were enrolled in this phase 2 trial. Treatment consisted of 6 to eight cycles of BACOPP. Residual tumor masses were irradiated. Of 60 eligible patients $51(85 \%)$ achieved $\mathrm{CR} / \mathrm{CRu}$. With a median observation time of 33 months, 18 patients died (30\%), including 7 treatmentassociated deaths. Grade 3/4 toxicities occurred in 52 (87\%) of patients. The PFS and OS rates for all patients at 3 years were $60 \%$ (95\% CI: $46 \%-73 \%)$, and $71 \%$ (95\% CI: 59\%-83\%) respectively. Thus, they considered this BACOPP regimen as active but compromised by a high toxicity in older HL patients.

The U.S. intergroup trial E2496 comparing ABVD vs. Stanford V (S.V) regimen has included 45 patients $\geq 60$ years treated with ABVD (23 cases) or S.V (22 cases). ${ }^{18}$ Adjunctive radiotherapy was delivered in $8.7 \%$ of ABVD patients and $43 \%$ S.V patients with different criteria between these two groups. In these patients, 5-year EFS and of $48 \%$ and 58\%, respectively, were much inferior to those obtained in younger patients (74\% and $90 \%$, respectively). Moreover, in this trial, Bleomycin lung toxicity was 24\%, mainly observed with ABVD (91\%), and the death rate due to Bleomycin toxicity was $18 \%$. The overall treatment-related mortality was $9 \%$ for older patients compared to $0.3 \%$ for patients aged $<60$ years. Overall, the death incidence without progression at two and five years were respectively $13 \%$ and $22 \%$ for elderly patients, and $2 \%$ and $9 \%$ for younger patients $(p<.0001)$. These results stressed that both ABVD and S.V regimens are toxic and difficult to use for patients aged above 60 and indicated the necessity of a precise evaluation and selection of patients before the choice of treatment.

Böll et al. $^{2}$ reported in 2013, for the GHSG, 117 cases of patients aged from 60 to 75 years (median 65) 
in a cohort of 1299 patients, included in the HD10 and HD11 trials, and treated with $4 \times$ ABVD for limited HL (stage I or II). Despite the selection of a favourable subgroup, the dose intensity delivered was reduced and only $59 \%$ of the patients achieved a relative dose intensity $>80 \%$ compared with $85 \%$ for younger patients. In $14 \%$, major protocol violations occurred, mainly because of excessive toxicity. Toxicities of WHO grade 3 or 4 occurred in $68 \%$, with $5 \%$ of treatment related mortality. The author conclude: "in patients $\geq 60$ years with $\mathrm{HL}$, four cycles of ABVD are associated with substantial dose reduction, treatment delay, toxicity and treatment-related mortality."

The escalated BEACOPP, which is the standard protocol for advanced-stage HL for the GHSG and is much more toxic that $\mathrm{ABVD}$, could not be proposed in patients aged over 60y : in their HD9 study the treatment related mortality (TRM) rate was high $(14.3 \%)$ in patients over 60 years and neutropenic infections were the main cause of $\mathrm{TRM}^{21}$

Role of Geriatric and Comorbidity Assessment in the Treatment Choice for HL in the Elderly. While definitions of the elderly patient remain vague, one can describe the ageing process as a gradual loss of adaptation to stress due to a diminution of the functional reserves of different organs. The process is variable from one individual to another and thus, the mean life expectancy of a 70 year-old patient varies from 6.7 to 18 years, and that of an 80-year old patient from 3.3 to 10.8 years. In addition to chronic pathologies (co-morbidities), geriatric syndromes (dementia, incontinence, under-nutrition, etc.) further complicate medical management. Clinical studies regularly exclude patients who are very old, frail or suffering from co-morbidities, which makes the results difficult to apply to these patients.

The clinician thus confronted a dual dilemma: should he treat with a proven but unpredictable risk of hyper toxicity, or undertreat a potentially curable patient and waste an opportunity. A recent review point out this dilemma in hematologic malignancies ${ }^{28}$ but data are very scarce for HL. A range of techniques have been advanced for assessing geriatric patients with a view to singling out those capable of receiving a potentially toxic dose of chemotherapy. The first step is to identify those most likely to benefit from comprehensive geriatric assessment (CGA). This method involves evaluating comorbidities, physical and psychic autonomy, nutritional and cognitive status, level of depression, mobility and balance. Unfortunately, the process is long, costly, complex and difficult to use in clinical units in the absence of a dedicated geriatrician. Other, simpler methods have been suggested but remain open to criticism and with contradictory results.

Recently, Soubeyran et al. reported interesting results of the Oncodage study in 1688 patients with solid tumors. They validated the G8 score, a relatively simple instrument to detect patients presenting at least one abnormal geriatric test among the following: Activity of Daily Living (ADL), Instrumental Activity of Daily Living (IADL), MMS, Geriatric Depression Scale 15 (GDS-15questions), Mini Nutritional Assessment (MNA), Timed Get up and Go, and evaluation of co-morbidities. ${ }^{29}$ Although constructed from patients with solid tumors, the G8 test appears to be useable in malignant hematology. In non-Hodgkin's lymphoma, the GELA group reported a prospective series of 150 DLBCL patients over 80 years treated with low doses of CHOP and full dose of rituximab. A good PS non-bulky disease $(<10 \mathrm{~cm})$, albumin $>35 \mathrm{~g} / \mathrm{l}$, extra-nodal sites $<2$, and high ADL level were associated with improved overall survival (OS) but in multivariate analysis, only albumin levels superior to $35 \mathrm{~g} / \mathrm{l}$ were associated with longer OS. ${ }^{30}$

In HL the only prospective study including a comorbidity assessment in a patient over 60 years seems to be the SHIELD study, previously described: ${ }^{23}$ this study seems to be more applicable to everyday life, and serves more as a reflection than a tool for the choice of treatment for an individual patient. In their retrospective study, Evens et al. showed that the combination of loss of activities of daily living and the age stratification of about 70 years gives a simple survival model in elderly HL. ${ }^{1}$ Several series have shown that the presence of co-morbidities is independently prognostic. ${ }^{12,31,32}$ Further trials should be designed to permit some flexibility to modify or adapt the drug dosing or the regimen, on the basis of firm objective criteria to avoid prohibitive toxicities. These trials may be able to optimize the duration of treatment to the response according to PET response (cfr. infra).

New Drugs: Brentuximab Vedotin (BV) is a promising novel antibody-drug conjugate targeting CD30 linked to a potent synthetic antitubulin chemotherapeutic agent, monomethyl auristatin E (MME). BV acts as a cell cycle-specific agent, like Vinca alkaloid drugs, and induces G2/M-phase growth arrest. ${ }^{33}$ A multicenter phase II trial of $\mathrm{BV}$ in $\mathrm{HL}$ patients, recurring after ASCT, demonstrated an overall response rate (ORR) of $75 \%$ and a complete response (CR) rate of $34 \%$ with a median duration of 20.5 months. ${ }^{34}$ The most common treatment-related adverse event was peripheral sensory neuropathy, recorded in $42 \%$ of patients, but with complete resolution after discontinuation of treatment in $50 \%$ of patients. A very similar incidence of grade 2 or 3 peripheral polyneuropathy $(52 \%)$ and symptom 
resolution (54\%) was reported by Gopal et al. in a small series $(\mathrm{N}=25)$ of patients treated with $\mathrm{BV}$ for recurring $\mathrm{HL}$ after allogeneic bone marrow transplantation. ${ }^{35}$ A higher rate of peripheral neuropathy was observed with weekly BV treatment versus treatment delivered every 3 weeks. ${ }^{36,37}$

No association of more frequent or severe neuropathy with old age was reported in any study, while a pre-existing neuropathy was found in more than half of cases of neurotoxicity. The second most frequent toxicity of grade 3 or more was haematological: anaemia (6-20\%) neutropenia (20\% in both series), and thrombocytopenia (8\%). A higher rate of peripheral neuropathy was observed with weekly BV treatment versus treatment delivered every 3 weeks. $^{36,37}$

Bendamustine hydrochloride $(\mathrm{Be})$ combines the antimetabolite activity of the purine-analogue structure with the alkylating property of the nitrogen mustard group. It is not a "new" drug, but its use in HL is recent. Because of its distinctive activity profile, Be may show limited cross resistance with agents usually employed for upfront and salvage treatments, and, therefore, it has been proposed for the treatment of relapsing/resistant HL. In two small phase II studies, enrolling nearly 70 patients aged 20-75, previously treated with 3-8 lines of chemotherapy (including autologous or allogeneic stem cell transplant), the ORR and CR rate, after a mean of 3.8 cycles of Bendamustine, administered intravenously at the dose of $120 \mathrm{mg} / \mathrm{m}^{2}$ on day 1 and 2 every 28 days, were, respectively, $50-53 \%$ and $29-33 \%$. The mean duration of response was 5 and 5.7 months. ${ }^{38,39}$ Corazzelli et al., in a third phase II study reported similar results with 68 courses of $\mathrm{Be}$ at $70-120 \mathrm{mg} / \mathrm{m}^{2}$ in 41 relapsed or refractory HL patients after 1-8 lines of chemotherapy, aged $18-85$ years. The ORR and CR rate were $58 \%$ and $31 \%$, respectively. ${ }^{40}$ Despite being relatively short PFS, these rates of response in such heavily pre-treated patients are encouraging.

The feasibility of Be treatment in patients aged 70 or more has been explored more frequently in Chronic Lymphocytic Leukemia (CLL). In a large retrospective study of 465 CLL patients treated with Bendamustine alone or in combination with rituximab, 91 were older than $70 .^{41}$ The most frequently administered dose and schedule was $76-98 \mathrm{mg} / \mathrm{m}^{2}$, twice per cycle every 21 days. Nearly $40 \%$ of patients experienced no cycle delay, grade 3-4 blood/bone marrow AE occurred in $18.8 \%$ and $25.3 \%$, respectively. In a multicenter phase II clinical trial from the German CLL Study Group, among 117 previously untreated CLL patients aged 3478 years, $25.6 \%$ were aged $>70 .{ }^{42}$ Be schedule was 90 $\mathrm{mg} / \mathrm{m} 2$ on days 1 and 2, every 28 days, associated to Rituximab. Grade 3 or 4 adverse events for neutropenia, thrombocytopenia, and anaemia were documented in $19.7 \%, 22.2 \%$, and $19.7 \%$ of patients, respectively. However, in both reports, the myelosuppression, due to bone marrow invasion by disease in all patients, and the association with Rituximab could have negatively affected the haematological toxicity. Finally, in a phase II trial in a small cohort of 20 elderly and frail patients affected by Diffuse Large B-Cell Lymphoma (DLBCL), with a mean age of 72 (51-86), Be was administered at a dose of $90 \mathrm{mg} / \mathrm{m}^{2}$ on days 1 and 2 in association with Rituximab on day 0 , every 28 days. ${ }^{43}$ The relative dose intensity (RDI) was $100 \%$. Granulocyte colony stimulating factor (GCS-F) was administered in only two patients and only three grade 3 WHO (1 leukopenia and 2 anaemia) and one grade 4 (thrombocytopenia) toxicities occurred.

Taken together, all these data makes $\mathrm{Be}$ an interesting candidate for use in combination for treatment of HL in elderly.

Other New Agents. Some other drugs are currently being studied and could potentially be used in the treatment of $\mathrm{HL}$ in the elderly because of a reduce toxicity compared to the usual chemotherapy regimen. Some epigenetic agents as HDACS inhibitors have shown encouraging results: for example, panobinostat, in a phase 2 trial, showed an ORR of $27 \% .^{44}$ Lenalidomide an immune-modulatory agent with antiangiogenic properties demonstrated a modest single agent activity, but may also be used in combination. ${ }^{44,45}$

Proposal for New Approaches. As the "gold standard" for younger patient, represented by ABVD, is more toxic and difficult to use with sufficient doseintensity and efficacy in the elderly, there is room for new approaches in the treatment of HL in the elderly.

Treatment Adapted to the Positron Emission Tomography (PET). Response. The early complete metabolic response, evaluated by PET after two cycles of ABVD, has been demonstrated to be the most important prognostic factor in 260 patients with advanced stage $\mathrm{HL}^{46}$ Many protocols are testing the possibility of shortening chemotherapy and/or omitting radiotherapy in adult patients, especially when in early favourable stage. In the elderly, this criterion could be used to propose chemotherapy of shorter duration, to avoid unnecessary toxicities. This strategy seems to be particularly attractive in the limited stages (I or II) in which radiotherapy can be use thereafter without excessive toxicity, even in the population of older patients. The major limitation of this strategy is that most elderly patients with HL have advanced stage, ${ }^{7}$ reducing the indications of radiotherapy. 
Combination of BV with other chemotherapy compounds. As $\mathrm{BV}$ is the only truly new drug with a major activity in HL without unexpected toxicities in the elderly, its use in a first line combination should be tested on elderly HL patients. Several reasons could account for the synergistic activity of BV with other antineoplastic drugs. First, differences between the cell types targeted by each class of compounds may account for improved activity. BV action is targeted against cells expressing CD30. CD 30 is found in Hodgkin's and Reed Sternberg (HRS) cells, which typically comprise only $0.1-1 \%$ of the total cell population within $\mathrm{HL}$ lesions. ${ }^{47}$ Chemotherapeutic agents, in addition to tumour cells, also target proliferating stromal cell infiltrates, which constitute the majority of the cell populations within HL lesions. By contrast, the cytotoxic effect of free MMAE diffused from $\mathrm{CD} 30+$ malignant cells on bystander cells may in part account for the significant antitumor activity of $\mathrm{BV}^{48}$ Secondly, differences in the mechanism of action between MME-based ADC and chemotherapeutic compounds may help to explain the increase in efficacy.

Frontline treatment of advanced-stage HL, with BV at the dose of $1.2 \mathrm{mg} / \mathrm{Kg}$ in association with $\mathrm{ABVD}$ (Doxorubicin, Vinblastine, Dacarbazine) or AVD, proved very active in a phase I multicentre trial, achieving respectively 95 and $96 \%$ of $\mathrm{CR}^{49}$ The most frequently reported (WHO grade $\geq 3$ ) adverse effects were neutropenia and peripheral sensory neuropathy present in $44 \%$ of the ABVD cohort, with 2 toxic deaths. ${ }^{49}$ These results with BV plus AVD are promising, but it is possible that this combination will remain too toxic for elderly patients.

Be seems to be a good candidate for such a combination as it have a non-cross-resistant

\section{References:}

1. Evens AM, Helenowski I, Ramsdale E, Nabhan C, Karmali R, Hanson B, Parsons B, Smith S, Larsen A, McKoy JM, Jovanovic B, Gregory S, Gordon LI, Smith SM. A retrospective multicenter analysis of elderly Hodgkin lymphoma: outcomes and prognostic factors in the modern era. Blood. 2012;119:692-5. http://dx.doi.org/10.1182/blood-2011-09-378414 PMid:22117038

2. Boll B, Gorgen H, Fuchs M, Pluetschow A, Eich HT, Bargetzi MJ, Weidmann E, Junghanss C, Greil R, Scherpe A, Schmalz O, Eichenauer DA, von Tresckow B, Rothe A, Diehl V, Engert A, Borchmann P. ABVD in older patients with early-stage Hodgkin lymphoma treated within the German Hodgkin Study Group HD10 and HD11 trials. J Clin Oncol. 2013;31:1522-9. http://dx.doi.org/10.1200/JCO.2012.45.4181 PMid:23509310

3. Brenner H, Gondos A, Pulte D. Ongoing improvement in longterm survival of patients with Hodgkin disease at all ages and recent catch-up of older patients. Blood. 2008;111:2977-83. http://dx.doi.org/10.1182/blood-2007-10-115493 PMid:18096762

4. Klimm B, Diehl V, Engert A. Hodgkin's lymphoma in the elderly: a different disease in patients over 60. Oncology. 2007;21:982-90. PMid:17715698

5. Evens AM, Sweetenham JW, Horning SJ. Hodgkin lymphoma in older patients: an uncommon disease in need of study. Oncology (Williston Park). 2008;22:1369-79. PMid:19086599 mechanism of action compared to $\mathrm{BV}$ combining the antimetabolite activity of the purine-analogue structure with the alkylating property of the nitrogen mustard group. In addition to primary effects on tumour cells, Be has shown a peculiar activity in HL by depleting the neoplastic microenvironment of tumour-supporting $\mathrm{T}$ and B-lymphocytes. ${ }^{50,51}$ This drug is already widely used in patients over 70 with CL or low grade lymphoma, and toxicity is easily manageable without dose reduction in case of renal insufficiency. ${ }^{52}$

Conclusions. Existing data does not define an optimal first line treatment for elderly $\mathrm{HL}$ patients. A comparison of existing trials is almost impossible because of the small number of patients included in the few published trials, lack of patient stratification (based on co-morbidities or age cohorts, for example), heterogeneous documentation of side effects such as lung toxicity, and varying endpoints chosen to assess efficacy of treatment protocols.

Patient selection will be crucial for an effective treatment strategy that could be modified based on interim PET imaging. In the absence of clinical data, it is necessary to individualize treatment decisions based on pre-treatment assessment scales and PET imaging. Based on our clinical experience, it is of utmost importance to monitor patients closely while on treatment in order to detect and control severe treatment related complications.

Acknowledgments. Sandrine Pacquelet-Cheli provided editorial assistance in the preparation of the manuscript. Katelyn Gordon and Anastasia Glazunova provided assistance for the revision of the manuscript.

6. Stark GL, Wood KM, Jack F, Angus B, Proctor SJ, Taylor PR Hodgkin's disease in the elderly: a population-based study. $\mathrm{Br} \mathrm{J}$ Haematol. 2002;119:432-40. http://dx.doi.org/10.1046/j.13652141.2002.03815.x PMid:12406082

7. Jagadeesh D, Diefenbach C, Evens AM. XII. Hodgkin lymphoma in older patients: challenges and opportunities to improve outcomes.Hematol Oncol. 2013;31 Suppl 1:69-75. http://dx.doi.org/10.1002/hon.2070 PMid:23775654

8. Hasenclever D, Diehl V. A prognostic score for advanced Hodgkin's disease. International Prognostic Factors Project on Advanced Hodgkin's Disease. N Engl J Med. 1998;339:1506-14. http://dx.doi.org/10.1056/NEJM199811193392104 PMid:9819449

9. Landgren O, Algernon C, Axdorph U, Nilsson B, Wedelin C, Porwit-MacDonald A, Grimfors G, Bjorkholm M. Hodgkin's lymphoma in the elderly with special reference to type and intensity of chemotherapy in relation to prognosis. Haematologica. 2003;88:438-44. PMid:12681971

10. Engert A, Ballova V, Haverkamp H, Pfistner B, Josting A, Duhmke E, Muller-Hermelink K, Diehl V. Hodgkin's lymphoma in elderly patients: a comprehensive retrospective analysis from the German Hodgkin's Study Group. J Clin Oncol. 2005;23:5052-60. http://dx.doi.org/10.1200/JCO.2005.11.080 PMid:15955904 
11. Evens AM, Antillon M, Aschebrook-Kilfoy B, Chiu BC. Racial disparities in Hodgkin's lymphoma: a comprehensive populationbased analysis. Ann Oncol. 2012;23:2128-37. http://dx.doi.org/10.1093/annonc/mdr578 PMid:22241896

12. Levis A, Anselmo AP, Ambrosetti A, Adamo F, Bertini M, Cavalieri E, Gavarotti P, Genua A, Liberati M, Pavone V, Pietrasanta D, Ricetti MM, Scalabrini DR, Salvi F, Vitolo U, Angelucci E, Boccadoro M, Gallo E, Mandelli F. VEPEMB in elderly Hodgkin's lymphoma patients. Results from an Intergruppo Italiano Linfomi (IIL) study. Ann Oncol. 2004;15:123-8. http://dx.doi.org/10.1093/annonc/mdh012 PMid:14679131

13. Bjorkholm M, Svedmyr E, Sjoberg J. How we treat elderly patients with Hodgkin lymphoma. Curr Opin Oncol. 2011;23:421-8. http://dx.doi.org/10.1097/CCO.0b013e328348c6c1 PMid:21681093

14. Proctor SJ, Wilkinson J, Sieniawski M. Hodgkin lymphoma in the elderly: a clinical review of treatment and outcome, past, present and future. Crit Rev Oncol Hematol. 2009;71:222-32. http://dx.doi.org/10.1016/j.critrevonc.2008.12.007 PMid:19179093

15. Weekes CD, Vose JM, Lynch JC, Weisenburger DD, Bierman PJ, Greiner T, Bociek G, Enke C, Bast M, Chan WC, Armitage JO. Hodgkin's disease in the elderly: improved treatment outcome with a doxorubicin-containing regimen. J Clin Oncol. 2002;20:1087-93. http://dx.doi.org/10.1200/JCO.20.4.1087 PMid:11844834

16. Evens AM, Hong F. How can outcomes be improved for older patients with Hodgkin lymphoma? J Clin Oncol. 2013;31:1502-5. http://dx.doi.org/10.1200/JCO.2012.47.3058 PMid:23509323

17. Canellos GP, Niedzwiecki D. Long-term follow-up of Hodgkin's disease trial. N Engl J Med. 2002;346:1417-8. http://dx.doi.org/10.1056/NEJM200205023461821

\section{PMid:11986425}

18. Evens AM, Hong F, Gordon LI, Fisher RI, Bartlett NL, Connors JM, Gascoyne RD, Wagner H, Gospodarowicz M, Cheson BD, Stiff PJ, Advani R, Miller TP, Hoppe RT, Kahl BS, Horning SJ. The efficacy and tolerability of adriamycin, bleomycin, vinblastine, dacarbazine and Stanford V in older Hodgkin lymphoma patients: a comprehensive analysis from the North American intergroup trial E2496. Br J Haematol. 2013;161:76-86. http://dx.doi.org/10.1111/bjh.12222 PMCid:PMC3906856

19. Azambuja E, Fleck JF, Batista RG, Menna Barreto SS. Bleomycin lung toxicity: who are the patients with increased risk? Pulm Pharmacol Ther. 2005;18:363-6. http://dx.doi.org/10.1016/j.pupt.2005.01.007

20. Ballova V, Ruffer JU, Haverkamp H, Pfistner B, Muller-Hermelink HK, Duhmke E, Worst P, Wilhelmy M, Naumann R, Hentrich M, Eich HT, Josting A, Loffler M, Diehl V, Engert A. A prospectively randomized trial carried out by the German Hodgkin Study Group (GHSG) for elderly patients with advanced Hodgkin's disease comparing BEACOPP baseline and COPP-ABVD (study HD9elderly). Ann Oncol. 2005;16:124-31. http://dx.doi.org/10.1093/annonc/mdi023 PMid:15598949

21. Wongso D, Fuchs M, Plutschow A, Klimm B, Sasse S, Hertenstein B, Maschmeyer G, Vieler T, Duhrsen U, Lindemann W, Aulitzky W, Diehl V, Borchmann P, Engert A. Treatment-related mortality in patients with advanced-stage hodgkin lymphoma: an analysis of the german hodgkin study group. J Clin Oncol. 2013;31:2819-24. http://dx.doi.org/10.1200/JCO.2012.47.9774 PMid:23796987

22. Macpherson N, Klasa RJ, Gascoyne R, O'Reilly SE, Voss N, Connors JM. Treatment of elderly Hodgkin's lymphoma patients with a novel 5-drug regimen (ODBEP): a phase II study.Leuk Lymphoma. 2002;43:1395-402. http://dx.doi.org/10.1080/10428190290033332 PMid:12389619

23. Proctor SJ, Wilkinson J, Jones G, Watson GC, Lucraft HH, Mainou-Fowler T, Culligan D, Galloway MJ, Wood KM, McNally RJ, James PW, Goodlad JR. Evaluation of treatment outcome in 175 patients with Hodgkin lymphoma aged 60 years or over: the SHIELD study. Blood. 2012;119:6005-15. http://dx.doi.org/10.1182/blood-2011-12-396556 PMid:22577177

24. Boll B, Bredenfeld H, Gorgen H, Halbsguth T, Eich HT, Soekler M, Markova J, Keller U, Graeven U, Kremers S, Geissler M, Trenn G, Fuchs M, von Tresckow B, Eichenauer DA, Borchmann P, Engert A. Phase 2 study of PVAG (prednisone, vinblastine, doxorubicin, gemcitabine) in elderly patients with early unfavorable or advanced stage Hodgkin lymphoma. Blood. 2011;118:6292-8. http://dx.doi.org/10.1182/blood-2011-07-368167 PMid:21917759

25. Kolstad A, Nome O, Delabie J, Lauritzsen GF, Fossa A, Holte H Standard CHOP-21 as first line therapy for elderly patients with Hodgkin's lymphoma. Leuk Lymphoma. 2007;48:570-6. http://dx.doi.org/10.1080/10428190601126610 PMid:17454601

26. Klimm B, Eich HT, Haverkamp H, Lohri A, Koch P, Boissevain F, Trenn G, Worst P, Duhmke E, Muller RP, Muller-Hermelink K, Pfistner B, Diehl V, Engert A. Poorer outcome of elderly patients treated with extended-field radiotherapy compared with involvedfield radiotherapy after chemotherapy for Hodgkin's lymphoma: an analysis from the German Hodgkin Study Group. Ann Oncol. 2007;18:357-63. $\quad$ http://dx.doi.org/10.1093/annonc/mdl379 PMid:17071932

27. Halbsguth TV, Nogova L, Mueller H, Sieniawski M, Eichenauer DA, Schober T, Nisters-Backes H, Borchmann P, Diehl V, Engert A, Josting A. Phase 2 study of BACOPP (bleomycin, adriamycin, cyclophosphamide, vincristine, procarbazine, and prednisone) in older patients with Hodgkin lymphoma: a report from the German Hodgkin Study Group (GHSG). Blood. 2010;116:2026-32. http://dx.doi.org/10.1182/blood-2009-11-253211 PMid:20551376

28. Peyrade F, Gastaud L, Re D, Pacquelet-Cheli S, Thyss A. Treatment decisions for elderly patients with haematological malignancies: a dilemma. Lancet Oncol. 2012;13:e344-52. http://dx.doi.org/10.1016/S1470-2045(12)70234-6

29. Soubeyran P. Validation of the G8 screening tool in geriatric oncology: The ONCODAGE project. ASCO meeting 2011 (Abstract 9001).

30. Peyrade F, Jardin F, Thieblemont C, Thyss A, Emile JF, Castaigne S, Coiffier B, Haioun C, Bologna S, Fitoussi O, Lepeu G, Fruchart C, Bordessoule D, Blanc M, Delarue R, Janvier M, Salles B, Andre M, Fournier M, Gaulard P, Tilly H. Attenuated immunochemotherapy regimen (R-miniCHOP) in elderly patients older than 80 years with diffuse large B-cell lymphoma: a multicentre, single-arm, phase 2 trial. Lancet Oncol. 2011;12:4608. http://dx.doi.org/10.1016/S1470-2045(11)70069-9

31. Guinee VF, Giacco GG, Durand M, van den Blink JW, Gustavsson A, McVie JG, Zewuster R, Dische S, Fahey T, Lane W. The prognosis of Hodgkin's disease in older adults. J Clin Oncol. 1991;9:947-53. PMid:2033430

32. van Spronsen DJ, Janssen-Heijnen ML, Lemmens VE, Peters WG, Coebergh JW. Independent prognostic effect of co-morbidity in lymphoma patients: results of the population-based Eindhoven Cancer Registry. Eur J Cancer. 2005;41:1051-7. http://dx.doi.org/10.1016/j.ejca.2005.01.010 PMid:15862755

33. Francisco JA, Cerveny CG, Meyer DL, Mixan BJ, Klussman K, Chace DF, Rejniak SX, Gordon KA, DeBlanc R, Toki BE, Law CL, Doronina SO, Siegall CB, Senter PD, Wahl AF. cAC10vcMMAE, an anti-CD30-monomethyl auristatin E conjugate with potent and selective antitumor activity. Blood. 2003;102:1458-65. http://dx.doi.org/10.1182/blood-2003-01-0039 PMid:12714494

34. Younes A, Gopal AK, Smith SE, Ansell SM, Rosenblatt JD, Savage KJ, Ramchandren R, Bartlett NL, Cheson BD, de Vos S, Forero-Torres A, Moskowitz CH, Connors JM, Engert A, Larsen EK, Kennedy DA, Sievers EL, Chen R. Results of a pivotal phase II study of brentuximab vedotin for patients with relapsed or refractory Hodgkin's lymphoma. J Clin Oncol. 2012;30:2183-9. http://dx.doi.org/10.1200/JCO.2011.38.0410 PMid:22454421 PMCid:PMC3646316

35. Gopal AK, Ramchandren R, O'Connor OA, Berryman RB, Advani RH, Chen R, Smith SE, Cooper M, Rothe A, Matous JV, Grove LE, Zain J. Safety and efficacy of brentuximab vedotin for Hodgkin lymphoma recurring after allogeneic stem cell transplantation. Blood. 2012;120:560-8. http://dx.doi.org/10.1182/blood-2011-12-397893 PMid:22510871 PMCid:PMC3731651

36. Younes A, Bartlett NL, Leonard JP, Kennedy DA, Lynch CM, Sievers EL, Forero-Torres A. Brentuximab vedotin (SGN-35) for relapsed CD30-positive lymphomas. N Engl J Med. 2010;363:1812-21. $\quad$ http://dx.doi.org/10.1056/NEJMoa1002965 PMid:21047225

37. Fanale MA, Forero-Torres A, Rosenblatt JD, Advani RH, Franklin AR, Kennedy DA, Han TH, Sievers EL, Bartlett NL. A phase I weekly dosing study of brentuximab vedotin in patients with relapsed/refractory CD30-positive hematologic malignancies. Clin 
Cancer Res. 2012;18:248-55. http://dx.doi.org/10.1158/10780432.CCR-11-1425 PMid:22080439

38. Ghesquieres H, Stamatoullas A, Casasnovas O, Morschhauser F, Gyan E, Gabarre J, Malphettes M, Clement L, Ferlay C, Brice P. Clinical experience of bendamustine in relapsed or refractory Hodgkin lymphoma: a retrospective analysis of the French compassionate use program in 28 patients. Leuk Lymphoma. 2013 http://dx.doi.org/10.3109/10428194.2013.776165

39. Moskowitz AJ, Hamlin PA, Jr., Perales MA, Gerecitano J, Horwitz SM, Matasar MJ, Noy A, Palomba ML, Portlock CS, Straus DJ, Graustein T, Zelenetz AD, Moskowitz CH. Phase II study of bendamustine in relapsed and refractory Hodgkin lymphoma. J Clin Oncol. 2013;31:456-60.

http://dx.doi.org/10.1200/JCO.2012.45.3308 PMid:23248254 PMCid:PMC3862960

40. Corazzelli G, Angrilli F, D'Arco A, Ferrara F, Musto P, Guarini A, Cox MC, Stelitano C, Storti S, Iannitto E, Falorio S, Califano C, Amore A, Arcamone M, De Filippi R, Pinto A. Efficacy and safety of bendamustine for the treatment of patients with recurring Hodgkin lymphoma. $\mathrm{Br} \quad \mathrm{J}$ Haematol. 2013;160:207-15. http://dx.doi.org/10.1111/bjh.12120 PMid:23167437

41. Kolibaba KS, Sterchele JA, Joshi AD, Forsyth M, Alwon E, Beygi H, Kennealey GT. Demographics, treatment patterns, safety, and real-world effectiveness in patients aged 70 years and over with chronic lymphocytic leukemia receiving bendamustine with or without rituximab: a retrospective study. Ther Adv Hematol. 2013;4:157-71. http://dx.doi.org/10.1177/2040620713478629 PMid:23730494 PMCid:PMC3666446

42. Fischer K, Cramer P, Busch R, Bottcher S, Bahlo J, Schubert J, Pfluger KH, Schott S, Goede V, Isfort S, von Tresckow J, Fink AM, Buhler A, Winkler D, Kreuzer KA, Staib P, Ritgen M, Kneba M, Dohner H, Eichhorst BF, Hallek M, Stilgenbauer S, Wendtner $\mathrm{CM}$. Bendamustine in combination with rituximab for previously untreated patients with chronic lymphocytic leukemia: a multicenter phase II trial of the German Chronic Lymphocytic Leukemia Study Group. J Clin Oncol. 2012;30:3209-16. http://dx.doi.org/10.1200/JCO.2011.39.2688 PMid:22869884

43. Horn J, Kleber M, Hieke S, Schmitt-Graff A, Wasch R, Engelhardt M. Treatment option of bendamustine in combination with rituximab in elderly and frail patients with aggressive B-nonHodgkin lymphoma: rational, efficacy, and tolerance. Ann Hematol. 2012;91:1579-86. http://dx.doi.org/10.1007/s00277-0121503-5 PMid:22752146

44. Younes A, Sureda A, Ben-Yehuda D, Zinzani PL, Ong TC, Prince HM, Harrison SJ, Kirschbaum M, Johnston P, Gallagher J, Le Corre C, Shen A, Engert A. Panobinostat in patients with relapsed/refractory Hodgkin's lymphoma after autologous stem-cell transplantation: results of a phase II study. J Clin Oncol 2012;30:2197-203. http://dx.doi.org/10.1200/JCO.2011.38.1350 PMid:22547596

45. Fehniger TA, Larson S, Trinkaus K, Siegel MJ, Cashen AF, Blum KA, Fenske TS, Hurd DD, Goy A, Schneider SE, Keppel CR, Wagner-Johnston ND, Carson KR, Bartlett NL. A phase 2 multicenter study of lenalidomide in relapsed or refractory classical Hodgkin lymphoma. Blood. 2011;118:5119-25. http://dx.doi.org/10.1182/blood-2011-07-362475 PMid:2193770 PMCid:PMC3217400

46. Gallamini A, Hutchings M, Rigacci L, Specht L, Merli F, Hansen M, Patti C, Loft A, Di Raimondo F, D'Amore F, Biggi A, Vitolo U, Stelitano C, Sancetta R, Trentin L, Luminari S, Iannitto E, Vivian S, Pierri I, Levis A. Early interim 2-[18F]fluoro-2-deoxy-Dglucose positron emission tomography is prognostically superior to international prognostic score in advanced-stage Hodgkin's lymphoma: a report from a joint Italian-Danish study. J Clin Oncol. 2007;25:3746-52. http://dx.doi.org/10.1200/JCO.2007.11.6525 PMid:17646666

47. Bai M, Papoudou-Bai A, Kitsoulis P, Horianopoulos N, Kamina S, Agnantis NJ, Kanavaros P. Cell cycle and apoptosis deregulation in classical Hodgkin lymphomas.In Vivo. 2005;19:439-53 PMid:15796209

48. Katz J, Janik JE, Younes A. Brentuximab Vedotin (SGN-35). Clin Cancer Res. 2011;17:6428-36. http://dx.doi.org/10.1158/10780432.CCR-11-0488 PMid:22003070

49. Ansell SM, Connors JM, Park SI, O'Maera MM, Younes A Frontline therapy with Brentuximab Vedotin combined with $\mathrm{ABVD}$ or $\mathrm{AVD}$ in patients with newly diagnosed advanced stage Hodgkin Lymphoma. Haematologica (9th symposium on Hodgkin Lymphoma) 2013,98, suppl 2: abstract 005

50. Aldinucci D, Gloghini A, Pinto A, De Filippi R, Carbone A. The classical Hodgkin's lymphoma microenvironment and its role in promoting tumour growth and immune escape. J Pathol 2010;221:248-63. http://dx.doi.org/10.1002/path.2711 PMid:20527019

51. Steidl C, Connors JM, Gascoyne RD. Molecular pathogenesis of Hodgkin's lymphoma: increasing evidence of the importance of the microenvironment. J Clin Oncol. 2011;29:1812-26 http://dx.doi.org/10.1200/JCO.2010.32.8401 PMid:21483001

52. Brugger W, Ghielmini M. Bendamustine in indolent non-Hodgkin's lymphoma: a practice guide for patient management. Oncologist 2013;18:954-64. http://dx.doi.org/10.1634/theoncologist.20130079 PMid:23900001 